\title{
Obstetrical risk factors of ELBW
}

\author{
Nicola Rizzo ${ }^{*}$, Giuliana Simonazzi, Alessandra Curti \\ From XXI Congress of the Italian Society of Neonatology \\ Palermo, Italy. 24-26 September 2015
}

Preterm birth is the leading cause of perinatal morbidity and mortality worldwide [1]. It contributes to $70 \%$ of neonatal mortality and approximately half of long-term neurodevelopmental disabilities [2]. The obstetrics precursors leading preterm birth are delivery for maternal or fetal indications, spontaneous preterm labour with intact membranes and preterm premature rupture of membranes (pPROM) [3]. It is estimated that about $30-35 \%$ of all preterm births are indicated, 40-45\% follow spontaneous preterm labour and $25-30 \%$ occur after pPROM [3].

Premature infants born at a gestational age of 32 weeks or less are obviously at greatest risk. The term "extreme low birthweight" (ELBW) is used to identify newborns with birthweight less than $1000 \mathrm{~g}$. Although their prevalence is less than $1 \%$, these newborns disproportionately account for nearly one-half of all perinatal deaths [4].

Antecedent risk factors for ELBW neonates, though geographically heterogeneous, include nulliparity and multiple gestations, each accounting for one-third and one-fourth of all births, respectively [5]. Spontaneous preterm labor precedes $34 \%$ of these deliveries and premature rupture of membranes in $25 \%$. The pregnancy is complicated by hypertensive disease in about $20 \%$ of cases and bleeding and chorioamnionitis in 18\%, respectively. Moreover, small for gestational age infants rate ranged from 16 to $20 \%$. When the frequencies of these factors is compared between the United States and other countries, PROM rate is similar between the groups (25\% vs. $26 \%$, respectively), while others are not (chorioamnionitis: $18 \%$ vs. $37 \%$, respectively). These variations may be due to publication bias, differences in maternal demographic characteristics, differences underlying burden of maternal or fetal illness, and/or differences in obstetrical practice patterns.

\section{Published: 24 September 2015}

\footnotetext{
* Correspondence: nicola.rizzo@unibo.it

Obstetrics and Prenatal Medicine - S.Orsola Hospital, Alma Mater Studiorum - Bologna University, Italy
}

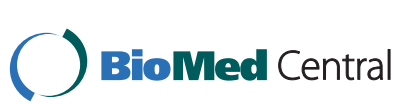

(c) 2015 Rizzo et al. This is an Open Access article distributed under the terms of the Creative Commons Attribution License (http:// creativecommons.org/licenses/by/4.0), which permits unrestricted use, distribution, and reproduction in any medium, provided the original work is properly cited. The Creative Commons Public Domain Dedication waiver (http://creativecommons.org/publicdomain/ zero/1.0/) applies to the data made available in this article, unless otherwise stated.
References
1. Goldenberg RL, Culhane JF, lams JD, Romero R: Epidemiology and causes of preterm birth. Lancet 2008, 371:75-84.

2. Mathews TJ, Menacker F, MacDorman MF: Infant mortality statistics from the 2002 period: linked birth/infant death data set. Natl Vital Stat Rep 2004, 53:1-29.

3. American College of Obstetricians and Gynecologists: Perinatal care at the threshold of viability; ACOG practice bulletin no. 38. Washington, DC: ACOG; 2002, reaffirmed 2010

4. Chauhan SP, Ananth CV: Periviable births: epidemiology and obstetrical antecedents. Semin Perinatol 2013, 37(6):382-388.

doi:10.1186/1824-7288-41-S1-A35

Cite this article as: Rizzo et al:: Obstetrical risk factors of ELBW. Italian Journal of Pediatrics 2015 41(Suppl 1):A35.
Submit your next manuscript to BioMed Central

- Convenient online submission

- Thorough peer review

- No space constraints or color figure charges

- Immediate publication on acceptance

- Inclusion in PubMed, CAS, Scopus and Google Scholar

- Research which is freely available for redistribution and take full advantage of: 